\title{
System of indicators for monitoring specially protected natural areas
}

\author{
Valentina Okmyanskaya ${ }^{1,{ }^{*}}$ and Olga Bogdanova ${ }^{1}$ \\ ${ }^{1}$ Industrial University of Tyumen», 625000 Tyumen, Russia
}

\begin{abstract}
In the context of the aggravation of environmental problems, in particular those related to the use of forest resources, mineral and fuel and energy resources, the violation and degradation of natural ecosystems in large areas, it became necessary to preserve unique areas of the earth's surface. Monitoring of protected areas is an effective tool for maintaining unique natural complexes in a high-quality condition, reducing the level of degradation of the components of the natural environment. Currently, specially protected natural areas of the Tyumen region are experiencing high anthropogenic loads associated with industrial, tourism, and investment activities. To develop a methodology for monitoring the lands of unique natural complexes and objects of the Tyumen region, the main factors that have a negative impact on natural complexes are identified.
\end{abstract}

\section{Introduction}

Specially protected natural areas (hereinafter referred to as protected areas) play a crucial role in maintaining a favorable ecological situation of the environment. Meanwhile, in the conditions of modern nature management, direct and indirect impact of man and his economic activities on natural complexes, the fact of the organization of protected areas does not always mean a reduction in anthropogenic impact. Therefore, at present, it is necessary to organize systematic observations of the state of protected areas, assess and predict changes in the components of protected areas under the influence of natural and anthropogenic factors.

Monitoring protected areas is a mandatory measure for the conservation of biodiversity and the maintenance of a favorable habitat, and therefore can be aimed at solving the most important tasks, such as:

1. Systematization of data on the components of the natural environment of protected areas, allowing to draw conclusions about the state of the environment and to provide timely measures for its protection.

2. Assessment of the degree of impact of natural and anthropogenic factors on the object of protected areas and development of action plans to reduce the negative impact.

3. Information support of state authorities, local self-government, legal entities, individual entrepreneurs, and citizens regarding the state of the environment within the boundaries of protected areas.

\footnotetext{
*Corresponding author: okmjanskajavm@tyuiu.ru
} 
4. Provision of up-to-date information of the state cadastre of protected areas of regional and local significance.

Currently, at the legislative level, there is no separate subsystem for monitoring protected areas within the framework of state environmental monitoring, and there is no single scientific basis for monitoring work, so each subject develops its own methodology, while in some regions it is absent. In the absence of a methodology at the regional level, various indicators and methodological approaches for monitoring protected areas are used, which does not allow them to be correctly compared for certain indicators.

While monitoring protected areas, special attention is paid to the study of the properties and condition of the main objects of protection - natural complexes, geological objects, plant and animal species listed in the Red Books. However, the main objects of protection do not always cover the entire area of protected areas, less valuable areas and often have huge areas, but their study did not get enough attention yet. Also, the developed methods do not always take into account a systematic approach to the concept of monitoring (observations-assessment-forecast), in the absence of tasks for assessing the state, data is collected that are insufficient for conducting evaluation work. In addition, there is also a low representativeness of the collected data, when the indicators obtained from one tract are extrapolated to the entire territory of the protected area without taking into account its landscape heterogeneity.

Consider the experience of other countries in monitoring protected areas (Table 1).

Table 1. Foreign experience in the organization and management of specially protected natural territories.

\begin{tabular}{|c|c|c|c|}
\hline A country & $\begin{array}{c}\text { Authority } \\
\text { managing } \\
\text { specially protected } \\
\text { natural territories }\end{array}$ & $\begin{array}{c}\text { Main features of the functioning of protected areas } \\
\text { National Park } \\
\text { Service (NPS) }\end{array}$ & $\begin{array}{l}\text { The system of protected areas is based on the } \\
\text { organization of national parks, the main purpose of which } \\
\text { is to create conditions for recreation of the population and } \\
\text { to obtain income from the implementation of the } \\
\text { recreational potential of these territories } \\
-\quad \text { GIS technology involvement in the scientific } \\
\text { activities of protected areas } \\
-\quad \text { regular inventory and monitoring of the } \\
\text { maximum possible range of various natural resources of } \\
\text { protected areas } \\
-\quad \text { monitoring in the territory of protected areas is } \\
\text { carried out in the following key areas: air and climate, } \\
\text { geology and soil, water, biota, anthropogenic activities } \\
\text { (including recreational activities), landscapes } \\
-\quad \text { a protocol containing information about the } \\
\text { goals, objectives, applied methods and objects of } \\
\text { monitoring, including map data, as well as a scientific } \\
\text { report on the results of monitoring is available on the } \\
\text { official NPS website for all users }\end{array}$ \\
\hline Great Britain & Natural England \\
$-\begin{array}{l}\text { private conservation organizations, as well as numerous } \\
\text { private foundations and members of the public, play an } \\
\text { important role in the protection and conservation of } \\
\text { protected areas } \\
\text { monitoring results are public information and are publicly } \\
\text { available on the official website of Natural England }\end{array}$ \\
\hline
\end{tabular}




\begin{tabular}{|c|c|c|}
\hline & & $\begin{array}{l}\text { - most protected areas are multipurpose } \\
\text { - support for small farms located within national parks is } \\
\text { an effective measure to preserve natural-territorial } \\
\text { complexes }\end{array}$ \\
\hline Spain & $\begin{array}{l}\text { Ministry of } \\
\text { Environment }\end{array}$ & $\begin{array}{l}\text { Monitoring of protected areas is carried out at } 3 \text { levels: } \\
\text { I level - monitoring is carried out in all parks, includes } \\
\text { programs for observing climate change, mapping the } \\
\text { spatial distribution of natural resources and habitats of } \\
\text { living organisms, tracking changes in forest ecosystems, } \\
\text { monitoring the functioning of ecosystems, as well as } \\
\text { general observations of avifauna } \\
\text { II level - monitoring is carried out for groups of parks with } \\
\text { similar climatic conditions } \\
\text { III level - monitoring of a specific park, taking into } \\
\text { account its unique features } \\
\text { - information on the spatial characteristics of specially } \\
\text { protected natural areas is publicly available }\end{array}$ \\
\hline Finland & $\begin{array}{c}\text { Forest Service of } \\
\text { Finland } \\
\text { (Metsähallitus) }\end{array}$ & $\begin{array}{l}\text { - the law on protected areas of wildlife does not contain } \\
\text { any special restrictions on the use of these areas, with } \\
\text { the exception of activities that could entail significant } \\
\text { changes in nature or landscapes } \\
\text { - protected areas are predominantly formed in forest } \\
\text { areas, within the framework of which protection regimes } \\
\text { are established } \\
\text { - educated protected objects serve as a territory for the } \\
\text { development of tourism } \\
\text { - regular inventory of biotopes and species is carried out } \\
\text { - monitoring of forests, fish stock, the most important } \\
\text { species for hunting, flora and fauna, birds and } \\
\text { environmental monitoring (water, air quality) is carried } \\
\text { out by the Research Institute }\end{array}$ \\
\hline
\end{tabular}

Having analyzed the organization and functioning of protected areas, as well as the organization of monitoring of unique natural complexes in foreign countries, we can draw the following conclusions:

1. A number of countries have developed a system for monitoring protected areas, which makes it possible to effectively manage these territories, as well as to protect them. When conducting monitoring studies, geoinformation systems containing large amounts of text and graphic information about protected areas are effectively used.

2. Scientific reports on the state of protected areas, compiled based on the results of monitoring, are publicly available.

3. In the United States, each interested user can create a researcher account and register their research program on the territory of any national park in the United States on the official website of the National Park Service (NPS), which allows interested parties to participate in the management and preservation of a unique object.

4. Maintaining protected areas in these foreign countries are allocated significant financial resources that allow us to effectively implement monitoring, which in turn allow you to preserve the unique properties of a particular object that allows you to use a site for the development of tourism and to obtain an economic benefit flowing to the budget of the country. For example, in Finland, for every dollar invested in a protected area, the state receives $\$ 10$. 
In the Tyumen Region, taking into account the autonomous districts, as of 01.01.2021, 139 objects of protected areas were formed, which occupy 118.1 thousand $\mathrm{km} 2$, which is $8.1 \%$ of the entire territory of a complex subject. Protected areas of the Tyumen region is located in the borders of several natural areas are of significant geological and geomorphological, soil, Botanical diversity, protected areas of the region cover an area of 0.3 hectares (natural monument Zinovsky mound) to 4113685,7 ha (state nature reserve of regional importance Yamal), the level of exposure it is possible to allocate the protected areas with high or low anthropogenic pressure.

The regional SPNA Tyumen region have a high level of anthropogenic impact, because of the intense economic development, especially the unique natural complexes of the Autonomous regions, the development of oil and gas, timber industry, traditional nature management of indigenous peoples of the North, the protected areas as places of rest without taking into account the permissible recreational activity, functional zoning of protected areas, and conscious of nature.

Currently, the methodology for monitoring the lands of protected areas in the Tyumen region is not sufficiently developed. Monitoring is carried out by the state authorities of the Tyumen region and subordinate organizations for individual components of the natural environment. However, the lack of comprehensive monitoring, as well as mutually coordinated activities of structures, tracking a limited number of indicators leads to deterioration of the state of protected areas, as well as low efficiency of management of these territories. (Article sizov and we)

Also, based on the information contained in open sources, it can be concluded that the monitoring of protected areas is carried out irregularly, there is no division of protected areas into groups depending on the level of anthropogenic impact. For example, the latest data on environmental monitoring of the components of the natural environment of the regional nature reserve "Sorumsky", located in the Beloyarsky district of the Khanty-Mansi Autonomous Okrug-Ugra, are presented for 2011, despite the fact that the main gas pipeline, oil pipeline, and year-round highway pass within the boundaries of the protected area.

In order to reduce the negative human impact on the unique natural ecosystems of the Tyumen region and their rational use, it is necessary to monitor the lands of protected areas-a set of works on monitoring, assessing and predicting the state and use of the lands of protected areas as the most important component of the natural and economic complex, using primarily remote sensing methods of the Earth. In this case, the concept of "land" includes the entire ecological system in which the object resides PA, that is the whole complex of environmental factors and natural conditions of production, which determine the actual state of land subject to soil, water bodies, vegetation, animal life.

As a result of the study, the authors identified anthropogenic factors of negative impact on the protected areas of the Tyumen region (Table 2).

Table 2. Anthropogenic factors of negative impact on the protected areas of the Tyumen region.

\begin{tabular}{|c|c|c|}
\hline Factors & Consequences & $\begin{array}{c}\text { Examples of protected } \\
\text { areas of the Tyumen } \\
\text { region }\end{array}$ \\
\hline $\begin{array}{l}\text { Exploration } \\
\text { and } \\
\text { development of } \\
\text { oil and gas } \\
\text { fields }\end{array}$ & $\begin{array}{l}\text { The oil and gas industry affects most of the } \\
\text { components of the natural environment-the } \\
\text { soil (the main volume of violations of the soil } \\
\text { cover is more than } 60 \% \text { in the development of } \\
\text { mineral deposits), air, surface and } \\
\text { underground water, flora, fauna, etc. It leads } \\
\text { to the formation of highly degraded } \\
\text { ecosystems in local areas }\end{array}$ & $\begin{array}{l}\text { Natural parks: Konda } \\
\text { Lakes; Numto; } \\
\text { Nature reserves: Zoromski; } \\
\text { Yamal; Messo-yakhinskiy; } \\
\text { Nadym }\end{array}$ \\
\hline
\end{tabular}




\begin{tabular}{|c|c|c|}
\hline $\begin{array}{l}\text { Timber } \\
\text { industry } \\
\text { development }\end{array}$ & $\begin{array}{l}\text { Forests within the boundaries of the protected } \\
\text { areas of the Tyumen region are undergoing } \\
\text { intensive development, there is an increase in } \\
\text { the volume of logging, a reduction in valuable } \\
\text { tree species. During the period of active } \\
\text { development of the forest resource base, a } \\
\text { large number of logging roads were laid on } \\
\text { the territory of unique natural complexes. The } \\
\text { impact of this factor leads to the degradation } \\
\text { of the fertile layer, the violation of all tiers of } \\
\text { vegetation, the migration of animals, the } \\
\text { disappearance of rare plant species, the } \\
\text { development of erosion, desertification, and } \\
\text { waterlogging on the land }\end{array}$ & $\begin{array}{l}\text { Natural parks: Kondinsky } \\
\text { lakes; Polar-Uralsky; } \\
\text { Samarovsky Chugas, } \\
\text { Siberian Uvaly } \\
\text { Nature reserves: Yamal, } \\
\text { Sorum } \\
\text { The memorial nature of the } \\
\text { far Nyris }\end{array}$ \\
\hline $\begin{array}{l}\text { Recreational } \\
\text { use of natural } \\
\text { resources }\end{array}$ & $\begin{array}{l}\text { Currently, there is no current data on the } \\
\text { permissible recreational load on the objects of } \\
\text { protected areas of the Tyumen region, within } \\
\text { the boundaries of which the organization and } \\
\text { arrangement of excursion ecological trails } \\
\text { and routes, tourist parking and recreation } \\
\text { areas, the construction of recreational } \\
\text { infrastructure, the organization of beaches are } \\
\text { allowed. This factor affects most often, the } \\
\text { intensity of recreation depends on the location } \\
\text { of protected areas, including the transport } \\
\text { accessibility of the territory and the proximity } \\
\text { of protected areas to settlements. Recreation } \\
\text { negatively affects the soil and vegetation } \\
\text { cover, leads to an increase in the area of } \\
\text { cluttered land, an increase in the risk of fire }\end{array}$ & $\begin{array}{l}\text { Natural parks: Kondinsky } \\
\text { lakes; Numto; Siberian } \\
\text { Rocks; Polar-Uralsky } \\
\text { Natural monuments: the } \\
\text { island of the Smolny; the } \\
\text { forest-swamp zone "Big } \\
\text { Naukowo"; Cescinsky } \\
\text { boron; lake system ay- } \\
\text { Novinka, UN-Novinka; } \\
\text { Ilichevskiy Bor }\end{array}$ \\
\hline $\begin{array}{l}\text { Traditional } \\
\text { nature } \\
\text { management of } \\
\text { the indigenous } \\
\text { small- } \\
\text { numbered } \\
\text { peoples of the } \\
\text { North }\end{array}$ & $\begin{array}{l}\text { Part of the territories of traditional nature } \\
\text { management of autonomous districts is } \\
\text { located within the boundaries of protected } \\
\text { areas. Traditional nature management } \\
\text { includes reindeer husbandry, hunting and } \\
\text { fishing, collecting wild plants, animal } \\
\text { husbandry, etc. The implementation of the } \\
\text { traditional image of the indigenous small- } \\
\text { numbered peoples of the North in the } \\
\text { protected areas is accompanied by the } \\
\text { construction of national homes, we lay trails }\end{array}$ & $\begin{array}{l}\text { Natural parks: Numto; } \\
\text { Siberian Rocks } \\
\text { Nature reserves: Undersky; } \\
\text { Zorumski; Surgut; Messo- } \\
\text { yakhinskiy; Sysko- } \\
\text { Voltarsi; Sobti Yugansk }\end{array}$ \\
\hline $\begin{array}{l}\text { Urban planning } \\
\text { factor }\end{array}$ & $\begin{array}{l}\text { Currently, more and more forested areas } \\
\text { located within the boundaries of cities, as } \\
\text { well as in suburban areas, acquire the status } \\
\text { of protected areas. Changes in the boundaries } \\
\text { of localities associated with the expansion of } \\
\text { their territory lead to the absorption and } \\
\text { inclusion of protected areas in the urban } \\
\text { environment. The implementation of the basic } \\
\text { environmental functions of protected areas } \\
\text { located in urban or suburban area, should be } \\
\text { limited to use of the forest population in } \\
\text { terms of the acceptable recreational activity } \\
\text { for environmental education, with a minimum } \\
\text { of site improvement. However, the } \\
\text { organization of recreation of the population in } \\
\text { protected areas, as a rule, is associated with }\end{array}$ & $\begin{array}{l}\text { Nature Park "Samarovsky } \\
\text { Chugas" Natural } \\
\text { monument Ovechy Island; } \\
\text { Zatyumensky Forest Park } \\
\text { Nature reserve "Pacholski» }\end{array}$ \\
\hline
\end{tabular}




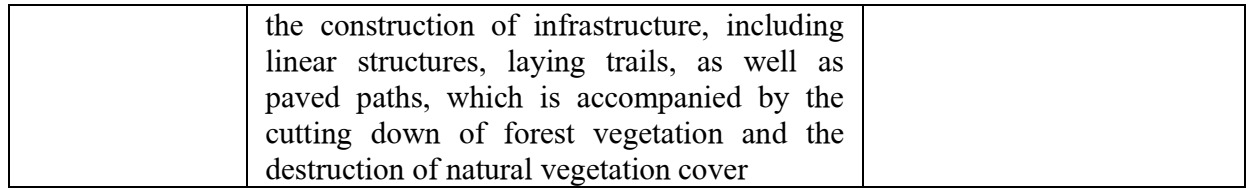

When planning and conducting monitoring studies of protected areas of the Tyumen region, it is advisable to take into account the features of economic activity in protected areas, as well as to identify the main factor of negative impact and the main components affecting the unique natural complex, in order to determine the technology for monitoring the land of protected areas of a complex subject.

When assessing the degree of impact of each factor on protected areas, it is necessary to rely on the following parameters: $\mathrm{K}$ - the amount (volume of exposure); $\mathrm{P}$ - the features of the spread of exposure; $\mathrm{C}-$ the degree of risk of exposure. The value of each specified parameter accepts from 1 to 3 points depending on the quantitative impact indicator, the ratio of exposures with regulations; of the nature of the distribution, severity of exposure. As a result of multiplying these points assigned to the parameters, the final score is obtained, which characterizes the degree of impact of this factor on protected areas.

Let us consider the features of calculating the degree of impact of exploration and development of oil and gas fields on protected areas (Table 3).

Table 3. Overall score score by the amount (volume) of exposure (K).

\begin{tabular}{|c|c|c|c|c|}
\hline \multirow{2}{*}{$\begin{array}{l}\text { The impact on } \\
\text { the environment }\end{array}$} & \multicolumn{3}{|c|}{ The Points - Quantity (K) } & \multirow{2}{*}{ Notes } \\
\hline & 1 point & 2 points & 3 points & \\
\hline $\begin{array}{l}\text { Air emissions, } \\
\text { tons / year: } \\
\text { For point sources } \\
\text { For distributed } \\
\text { sources }\end{array}$ & $\begin{array}{l}<5 \\
<50\end{array}$ & $\begin{array}{c}5-25 \\
50-300\end{array}$ & $\begin{array}{l}>25 \\
>300\end{array}$ & $\begin{array}{l}\text { Must be } \\
\text { rated } \\
\text { according } \\
\text { to hazard } \\
\text { classes }\end{array}$ \\
\hline $\begin{array}{l}\text { Discharges of } \\
\text { pollutants from } \\
\text { wastewater, tons } \\
\text { / year }\end{array}$ & $<0,5$ & $0,5-2$ & $>2$ & $\begin{array}{l}\text { Must be } \\
\text { rated } \\
\text { according } \\
\text { to hazard } \\
\text { classes }\end{array}$ \\
\hline $\begin{array}{l}\text { Waste, tons / } \\
\text { year }\end{array}$ & $<10$ & $10-100$ & $>100$ & $\begin{array}{l}\text { Must be } \\
\text { rated } \\
\text { according } \\
\text { to hazard } \\
\text { classes }\end{array}$ \\
\hline $\begin{array}{l}\text { The consumption } \\
\text { of water, cubic } \\
\text { metres per year }\end{array}$ & $\begin{array}{l}\text { Does not exceed } \\
\text { the established } \\
\text { standard, or is not } \\
\text { established }\end{array}$ & & $\begin{array}{c}\text { Exceeds the } \\
\text { established } \\
\text { standard, or the } \\
\text { standard is not } \\
\text { required }\end{array}$ & \\
\hline $\begin{array}{l}\text { Electric energy } \\
\text { consumption, } \\
\text { thousand } \mathrm{kW} * \mathrm{~h}\end{array}$ & $\begin{array}{c}<100 \text { or custom } \\
\text { generation objects }\end{array}$ & $100-1000$ & $>1000$ & \\
\hline $\begin{array}{l}\text { Thermal energy } \\
\text { consumption, } \\
\text { Gcal per year }\end{array}$ & $\begin{array}{l}<100 \text { or custom } \\
\text { generation objects }\end{array}$ & $100-1000$ & $>1000$ & \\
\hline $\begin{array}{l}\text { Physical impact, } \\
\text { the number of } \\
\text { uncomfortable } \\
\text { days in a year }\end{array}$ & $<30$ & $30-300$ & $>300$ & \\
\hline
\end{tabular}




\begin{tabular}{|l|c|c|c|c|}
\hline $\begin{array}{l}\text { Radioactive } \\
\text { exposure }\end{array}$ & \multicolumn{3}{|c|}{$\begin{array}{c}\text { For liquid radioactive waste, the waste water criteria are used; for solid } \\
\text { radioactive waste, the waste criteria are used }\end{array}$} \\
\hline $\begin{array}{l}\text { Violation of the } \\
\text { soil cover. Area } \\
\text { of disturbed land, } \\
\text { ha }\end{array}$ & $<0,1$ & $0,1-1$ & $>1$ & \\
\hline $\begin{array}{l}\text { Risks and } \\
\text { accidents }\end{array}$ & $\begin{array}{c}\text { Within the } \\
\text { boundaries of a } \\
\text { production facility }\end{array}$ & $\begin{array}{c}\text { Within the } \\
\text { boundaries of the } \\
\text { sanitary } \\
\text { protection zone of } \\
\text { the object }\end{array}$ & $\begin{array}{c}\text { Within the } \\
\text { boundaries of the } \\
\text { territory of the } \\
\text { administrative } \\
\text { district of the } \\
\text { region the } \\
\text { location of the } \\
\text { object }\end{array}$ & \\
\hline Other impacts & Determined on the basis of expert assessments & \\
\hline
\end{tabular}

Table 4. Overall rating of scores for the dissemination of exposure $(\mathrm{P})$.

\begin{tabular}{|c|c|c|c|c|}
\hline \multirow{2}{*}{$\begin{array}{l}\text { The impact on } \\
\text { the } \\
\text { environment }\end{array}$} & \multicolumn{3}{|c|}{ The Points - Distribution (P) } & \multirow{2}{*}{ Notes } \\
\hline & 1 point & 2 points & 3 points & \\
\hline $\begin{array}{l}\text { Emissions to } \\
\text { the atmosphere }\end{array}$ & & & $\begin{array}{l}\text { Always equal to } \\
\text { three points }\end{array}$ & $\begin{array}{l}\text { Based on } \\
\text { global } \\
\text { distribution }\end{array}$ \\
\hline $\begin{array}{l}\text { Wastewater } \\
\text { discharges }\end{array}$ & $\begin{array}{l}\text { Discharge of } \\
\text { wastewater to } \\
\text { third-party } \\
\text { treatment } \\
\text { facilities or } \\
\text { discharge of } \\
\text { treated } \\
\text { wastewater into } \\
\text { surface water } \\
\text { bodies and } \\
\text { underground } \\
\text { horizons }\end{array}$ & $\begin{array}{l}\text { Discharge of } \\
\text { contaminated } \\
\text { wastewater into } \\
\text { underground } \\
\text { horizons, } \\
\text { filtration fields, } \\
\text { evaporation } \\
\text { ponds, or surface } \\
\text { water bodies after } \\
\text { local treatment } \\
\text { facilities in } \\
\text { excess of } \\
\text { established } \\
\text { standards }\end{array}$ & $\begin{array}{l}\text { Discharge of } \\
\text { contaminated } \\
\text { wastewater into } \\
\text { surface water } \\
\text { bodies and into } \\
\text { the treatment } \\
\text { terrain }\end{array}$ & $\begin{array}{l}\text { Must be rated } \\
\text { according to } \\
\text { hazard classes }\end{array}$ \\
\hline Waste & $\begin{array}{l}\text { Waste less than } \\
11 \text { months. } \\
\text { Accumulated in } \\
\text { the enterprise in } \\
\text { accordance with } \\
\text { the established } \\
\text { requirements, } \\
\text { used in the } \\
\text { enterprise or } \\
\text { transferred to } \\
\text { other enterprises } \\
\text { for use }\end{array}$ & $\begin{array}{l}\text { Waste less than } \\
11 \text { months. They } \\
\text { are accumulated } \\
\text { on the territory of } \\
\text { the enterprise in } \\
\text { accordance with } \\
\text { the established } \\
\text { requirements, } \\
\text { dewatered at the } \\
\text { enterprise, placed } \\
\text { on licensed } \\
\text { landfills or } \\
\text { transferred to } \\
\text { other enterprises } \\
\text { for dewatering, } \\
\text { placed on } \\
\text { licensed landfills }\end{array}$ & $\begin{array}{l}\text { Waste more than } \\
11 \text { months. } \\
\text { Stored on the } \\
\text { territory of the } \\
\text { enterprise or } \\
\text { placed in } \\
\text { unauthorized } \\
\text { landfills }\end{array}$ & $\begin{array}{l}\text { Must be rated } \\
\text { according to } \\
\text { hazard classes }\end{array}$ \\
\hline Water & & Always equal to & & The problem \\
\hline
\end{tabular}




\section{EMMFT-2020}

\begin{tabular}{|c|c|c|c|c|}
\hline consumption & & two points & & $\begin{array}{l}\text { on a regional } \\
\text { scale }\end{array}$ \\
\hline $\begin{array}{l}\text { Consumption } \\
\text { of electric and } \\
\text { thermal energy }\end{array}$ & & & $\begin{array}{l}\text { Always equal to } \\
\text { three points }\end{array}$ & $\begin{array}{l}\text { Based on } \\
\text { global } \\
\text { distribution }\end{array}$ \\
\hline $\begin{array}{l}\text { Physical } \\
\text { impact }\end{array}$ & $\begin{array}{l}\text { Does not go } \\
\text { beyond the } \\
\text { sanitary } \\
\text { protection zone }\end{array}$ & $\begin{array}{l}\text { Goes beyond the } \\
\text { sanitary } \\
\text { protection zone }\end{array}$ & & \\
\hline $\begin{array}{l}\text { Radioactive } \\
\text { exposure }\end{array}$ & \multicolumn{4}{|c|}{$\begin{array}{l}\text { For liquid radioactive waste, the waste water criteria are used; for solid } \\
\text { radioactive waste, the waste criteria are used }\end{array}$} \\
\hline $\begin{array}{l}\text { Violation of } \\
\text { the soil cover. }\end{array}$ & $\begin{array}{l}\text { The effect is only } \\
\text { on the surface of } \\
\text { the soil }\end{array}$ & $\begin{array}{l}\text { Removal of only } \\
\text { the upper humus } \\
\text { horizon of soils }\end{array}$ & $\begin{array}{l}\text { Removing the } \\
\text { entire soil profile }\end{array}$ & \\
\hline $\begin{array}{l}\text { Risks and } \\
\text { accidents }\end{array}$ & $\begin{array}{l}\text { The presence of } \\
\text { exposure is } \\
\text { known initially, } \\
\text { and / or detected } \\
\text { by visual } \\
\text { inspection }\end{array}$ & $\begin{array}{l}\text { The impact is } \\
\text { detected by the } \\
\text { results of } \\
\text { individual } \\
\text { measurements } \\
\text { and / or by } \\
\text { regular } \\
\text { monitoring }\end{array}$ & $\begin{array}{l}\text { It is detected } \\
\text { during special } \\
\text { studies }\end{array}$ & \\
\hline Other impacts & \multicolumn{4}{|c|}{ Determined on the basis of expert assessments } \\
\hline
\end{tabular}

Table 4. Overall rating of scores for severity of the effects (B).

\begin{tabular}{|c|c|c|c|c|}
\hline \multirow{2}{*}{$\begin{array}{l}\text { The impact } \\
\text { on the } \\
\text { environment }\end{array}$} & \multicolumn{3}{|c|}{ The Points - Impact (B) } & \multirow{2}{*}{ Notes } \\
\hline & 1 point & 2 points & 3 points & \\
\hline $\begin{array}{l}\text { Emissions to } \\
\text { the } \\
\text { atmosphere }\end{array}$ & $\begin{array}{l}\text { Substances of the } \\
4 \text { class of danger }\end{array}$ & $\begin{array}{l}\text { Substances of the } \\
2-3 \text { hazard class, } \\
\text { methane }\end{array}$ & $\begin{array}{l}\text { Substances of the } \\
1 \text { hazard class }\end{array}$ & $\begin{array}{l}\text { Must be rated } \\
\text { according to } \\
\text { hazard classes }\end{array}$ \\
\hline $\begin{array}{l}\text { Wastewater } \\
\text { discharges }\end{array}$ & $\begin{array}{l}\text { Substances of the } \\
4 \text { class of danger }\end{array}$ & $\begin{array}{l}\text { Substances of the } \\
2-3 \text { hazard class, } \\
\text { methane }\end{array}$ & $\begin{array}{l}\text { Substances of the } \\
1 \text { hazard class }\end{array}$ & $\begin{array}{l}\text { Must be rated } \\
\text { according to } \\
\text { hazard classes }\end{array}$ \\
\hline Waste & $\begin{array}{l}\text { Substances of the } \\
4 \text { class of danger }\end{array}$ & $\begin{array}{l}\text { Substances of the } \\
2-3 \text { hazard class, } \\
\text { methane }\end{array}$ & $\begin{array}{l}\text { Substances of the } \\
1 \text { hazard class }\end{array}$ & $\begin{array}{l}\text { Must be rated } \\
\text { according to } \\
\text { hazard classes }\end{array}$ \\
\hline $\begin{array}{l}\text { Water } \\
\text { consumption }\end{array}$ & & $\begin{array}{l}\text { Use of } \\
\text { underground } \\
\text { water from own } \\
\text { sources of water } \\
\text { supply. The use } \\
\text { of imported } \\
\text { water, or } \\
\text { centralized water } \\
\text { supply from } \\
\text { surface and } \\
\text { underground } \\
\text { sources of water }\end{array}$ & $\begin{array}{l}\text { Use of surface } \\
\text { water from own } \\
\text { water supply } \\
\text { sources }\end{array}$ & \\
\hline $\begin{array}{l}\text { Consumption } \\
\text { of electric and } \\
\text { thermal } \\
\text { energy }\end{array}$ & $\begin{array}{l}\text { Third-party } \\
\text { energy } \\
\text { generation } \\
\text { facilities (energy } \\
\text { purchase) }\end{array}$ & $\begin{array}{l}\text { Own energy } \\
\text { generation } \\
\text { facilities }\end{array}$ & & \\
\hline $\begin{array}{l}\text { Physical } \\
\text { impact }\end{array}$ & $\begin{array}{l}\text { The level of } \\
\text { physical }\end{array}$ & & $\begin{array}{l}\text { The level of } \\
\text { physical }\end{array}$ & \\
\hline
\end{tabular}




\begin{tabular}{|c|c|c|c|c|}
\hline & $\begin{array}{l}\text { exposure does } \\
\text { not exceed the } \\
\text { maximum } \\
\text { permissible } \\
\text { levels for a } \\
\text { working, } \\
\text { sanitary- } \\
\text { protected or } \\
\text { residential area }\end{array}$ & & $\begin{array}{l}\text { exposure exceeds } \\
\text { the maximum } \\
\text { permissible } \\
\text { levels for a } \\
\text { working, } \\
\text { sanitary- } \\
\text { protected or } \\
\text { residential area }\end{array}$ & \\
\hline $\begin{array}{l}\text { Radioactive } \\
\text { exposure }\end{array}$ & $\begin{array}{l}\text { Does not exceed } \\
\text { the established } \\
\text { standards }\end{array}$ & & $\begin{array}{l}\text { Exceeds the } \\
\text { established } \\
\text { standards }\end{array}$ & $\begin{array}{l}\text { It is set for each } \\
\text { type of } \\
\text { exposure }\end{array}$ \\
\hline $\begin{array}{l}\text { Violation of } \\
\text { the soil cover. }\end{array}$ & $\begin{array}{l}\text { The impact is } \\
\text { eliminated by } \\
\text { recultivation } \\
\text { without reducing } \\
\text { the fertile soil }\end{array}$ & $\begin{array}{l}\text { Recultivation can } \\
\text { be carried out } \\
\text { with deviations } \\
\text { from the norms, } \\
\text { it is possible to } \\
\text { reduce soil } \\
\text { fertility }\end{array}$ & $\begin{array}{l}\text { It is possible to } \\
\text { completely } \\
\text { degrade the soil } \\
\text { and remove it } \\
\text { from the crop } \\
\text { rotation }\end{array}$ & \\
\hline $\begin{array}{l}\text { Risks and } \\
\text { accidents }\end{array}$ & $\begin{array}{l}\text { Accidents with } \\
\text { environmental } \\
\text { damage } \\
\text { associated with } \\
\text { the assessed risk } \\
\text { did not occur }\end{array}$ & $\begin{array}{l}\text { Accidents with } \\
\text { environmental } \\
\text { damage } \\
\text { associated with } \\
\text { the assessed risk } \\
\text { occurred more } \\
\text { than a year ago }\end{array}$ & $\begin{array}{l}\text { Accidents with } \\
\text { environmental } \\
\text { damage related } \\
\text { to the assessed } \\
\text { risk occurred in } \\
\text { the current year }\end{array}$ & \\
\hline Other impacts & \multicolumn{4}{|c|}{ Determined on the basis of expert assessments } \\
\hline
\end{tabular}

Let us consider in more detail how environmental monitoring of natural environment components is carried out within the boundaries of regional protected areas in the KhantyMansiysk Autonomous Okrug-Ugra on the example of the regional nature park "Kondinsky Lakes", located in the Sovetsky District of the Autonomous Okrug. It should be noted that within the boundaries of the park there is a natural monument of local significance Lake Rank-Tur, which is under the jurisdiction and management of the Federal State Budgetary Institution "State Nature Reserve" Malaya Sosva " named after V. V. Raevsky", while the functions of managing the territory of the park "Kondinsky Lakes" are assigned to the budget institution of the Khanty-Mansi Autonomous Okrug-Ugra " Natural Park "Kondinsky Lakes" named after L. F. Stashkevich".

The park "Kondinsky Lakes" has a recreational value and covers an area of 43,900 hectares. The layout of the park boundaries is shown in Figure 1.

The Nature Park "Kondinsky Lakes" is crucial for the conservation and study of valuable natural complexes, rare plants and animals, and objects of historical and cultural heritage.

Its value is also due to the fact that the park has an international status and acts as a key ornithological territory intended for the conservation of rare and endangered bird species. This is due to the fact that on the territory of the natural park there is a unique water system of the Kondinsky Lakes, which is the main ecosystem of the protected areas. A white-tailed eagle nests on the territory of the Kondinsky Lakes Park; this species of birds is listed in the Red Book of IUCN 96, the Red Books of the Russian Federation, the Tyumen Region and the Khanty-Mansi Autonomous Okrug-Ugra. 


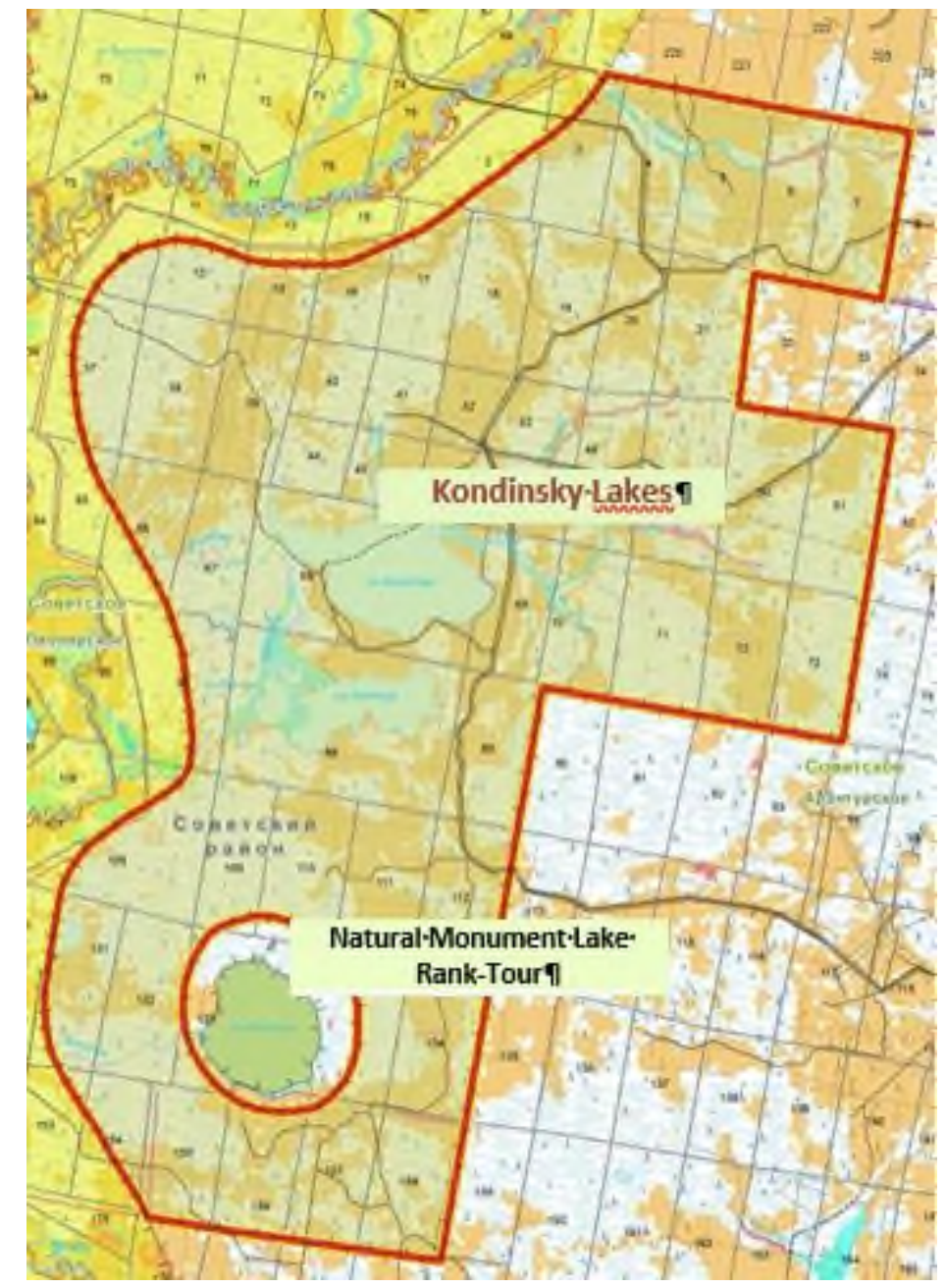

\section{Legend}

Border of the Kondinsky Lakes Natural

Fig. 1. Fragment of a map of the boundaries of the natural park "Kondinsky Lakes".

So, the Kondinsky Lakes Nature Park fulfills not only the tasks of preserving the reference natural complexes, landscapes, biodiversity, but also provides the conditions for the development of tourism activities, as well as subsoil use. Within the boundaries of the zone of limited nature use of the park, the development and operation of the Talnik oil field is carried out.

Depending on the degree of protection, protection and use of the natural park, taking into account local natural, historical, cultural and social features, the following functional zones are established, presented in table 2. 
Table 5. The composition of the functional zones of the Kondinsky Lakes Natural Park.

\begin{tabular}{|c|c|c|c|c|}
\hline $\begin{array}{l}\text { Functional } \\
\text { area }\end{array}$ & Territory composition & Purpose & $\begin{array}{c}\text { Area, } \\
\text { hectare }\end{array}$ & $\begin{array}{l}\text { Share in } \\
\text { the total } \\
\text { area, \% }\end{array}$ \\
\hline $\begin{array}{l}\text { Conservation } \\
\text { area }\end{array}$ & $\begin{array}{l}\text { - a site located in the quarters } \\
\text { of the forest fund of Arantur } \\
\text { forestry: } 10,12,14,37-39, \\
44-47,66-69,87-89,108- \\
11,131-133,153-156 ; \\
\text { - the stretch of the Lemia } \\
\text { river and the territory } \\
\text { between the river and the } \\
\text { northern border of the natural } \\
\text { park; } \\
\text { - eastern section, including } \\
\text { the southeastern part of } \\
\text { quarters } 50,51, \text { the } \\
\text { northeastern part } 9 \text { nv of } \\
\text { quarters } 72 \text { and } 73 \text { of } \\
\text { Arantursky forestry } \\
\text { - bands of water protection } \\
\text { zones of rivers }\end{array}$ & $\begin{array}{l}\text { Preservation in the } \\
\text { natural state of } \\
\text { typical mid-taiga } \\
\text { natural complexes } \\
\text { that perform water } \\
\text { protection, water } \\
\text { storage functions, } \\
\text { preserving the } \\
\text { biodiversity of the } \\
\text { territory }\end{array}$ & 22828 & $52 \%$ \\
\hline $\begin{array}{l}\text { Protected } \\
\text { Ecosystem } \\
\text { Subzone }\end{array}$ & $\begin{array}{l}\text {-a site located in the quarters } \\
\text { of the forest fund of Arantur } \\
\text { forestry: } 44-47,67-69,88-89 \text {, } \\
\text { 108-111, 131-133, 153-156; } \\
\text {-the water area of Lake Rank- } \\
\text { Tour and the coastal zone } 1 \\
\text { km wide }\end{array}$ & $\begin{array}{l}\text { Preservation of } \\
\text { natural ecosystems } \\
\text { in the process of } \\
\text { their natural } \\
\text { development, } \\
\text { conservation of } \\
\text { biodiversity of local } \\
\text { species of plants } \\
\text { and animals }\end{array}$ & 11853 & $27 \%$ \\
\hline $\begin{array}{l}\text { Environmenta } \\
1 \quad \text { Regime } \\
\text { Subzone }\end{array}$ & $\begin{array}{l}\text { - plots located in the quarters } \\
\text { of Arantursky forestry: } 10 \text {, } \\
12,14,37-39,66,87 ; \\
\text {-the stretch of the Lemia river } \\
\text { and the territory between the } \\
\text { river and the northern border } \\
\text { of the natural park; } \\
\text {-eastern section, including } \\
\text { the southeastern part of } \\
\text { quarters 50, 51, the } \\
\text { northeastern part } 9 \text { nv of } \\
\text { quarters } 72 \text { and } 73 \text { of } \\
\text { Arantursky forestry }\end{array}$ & $\begin{array}{l}\text { Promotion of self- } \\
\text { regulation and } \\
\text { restoration of } \\
\text { natural landscapes }\end{array}$ & 10975 & $25 \%$ \\
\hline $\begin{array}{l}\text { Recreation } \\
\text { area }\end{array}$ & $\begin{array}{l}\text { Northeast, Northwest, and } \\
\text { Southeast Parts of the Natural } \\
\text { Park }\end{array}$ & $\begin{array}{l}\begin{array}{l}\text { Ensuring optimal } \\
\text { conditions } \\
\text { recreation of } \\
\text { population, } \\
\text { organization } \\
\text { recreation, }\end{array} \\
\begin{array}{l}\text { combined with } \\
\text { cognitive, tourist, }\end{array} \\
\begin{array}{l}\text { sightseeing and } \\
\text { other activities }\end{array}\end{array}$ & 12731 & $29 \%$ \\
\hline
\end{tabular}




\begin{tabular}{|c|c|c|c|c|}
\hline $\begin{array}{l}\text { The zone of } \\
\text { protection of } \\
\text { historical and } \\
\text { cultural } \\
\text { complexes } \\
\text { and objects }\end{array}$ & $\begin{array}{l}\text { More than } 200 \text { identified } \\
\text { objects of historical and } \\
\text { cultural heritage are grouped } \\
\text { in } 36 \text { sites and allocated at } \\
\text { the locations of archeological } \\
\text { monuments }\end{array}$ & $\begin{array}{l}\text { Preservation of } \\
\text { historical and } \\
\text { cultural monuments } \\
\text { for use in scientific, } \\
\text { educational and } \\
\text { recreational } \\
\text { purposes }\end{array}$ & 878 & $2 \%$ \\
\hline $\begin{array}{l}\text { Restricted } \\
\text { area }\end{array}$ & $\begin{array}{l}\text { The northern part of the } \\
\text { natural park, which includes: } \\
\text { - areas where exploratory } \\
\text { exploration drilling sites, } \\
\text { cluster sites are located; } \\
\text { - sections occupied by linear } \\
\text { facilities - pipelines, power } \\
\text { lines, infield roads, and other } \\
\text { oilfield infrastructure } \\
\text { facilities; } \\
\text { - areas directly adjacent to } \\
\text { the field facilities and } \\
\text { experiencing the most } \\
\text { pronounced anthropogenic } \\
\text { impact }\end{array}$ & $\begin{array}{l}\text { For the } \\
\text { implementation of } \\
\text { the tasks of nature } \\
\text { users within the } \\
\text { framework of a } \\
\text { regime specially } \\
\text { established during } \\
\text { the work of the } \\
\text { project, taking into } \\
\text { account the } \\
\text { assessment of the } \\
\text { environmental } \\
\text { impact within the } \\
\text { boundaries of the } \\
\text { land allotment }\end{array}$ & 7463 & $17 \%$ \\
\hline \multicolumn{3}{|c|}{ Total } & 43900 & $100 \%$ \\
\hline
\end{tabular}

Figure 2 presents a map of the functional zoning of the natural park, developed on the basis of a full-scale study of the territory, landscape mapping, studies of the terrain features.

Based on the data presented in table 2, we can draw the following conclusions:

1. On the territory of the Nature Park "Kondinsky Lakes", various special protection and regimes have been established depending on the ecological and recreational value of natural sites, a large part of the territory is occupied by natural protection zone, within the borders of which any activity involving changes or destruction of the natural environment of protected areas or its components is prohibited.

2. $29 \%$ of the park's territory is used by the population for recreation, gathering wild plants, amateur hunting and fishing, while the developed limits for recreational nature management are not always respected. Also, roads were laid on the territory of the park to ensure transport accessibility, the use of which leads to the transformation of sections of the natural complex.

3. The development of oil field facilities within the boundaries of the restricted use zone leads to significant negative consequences for the entire territory of the park. 


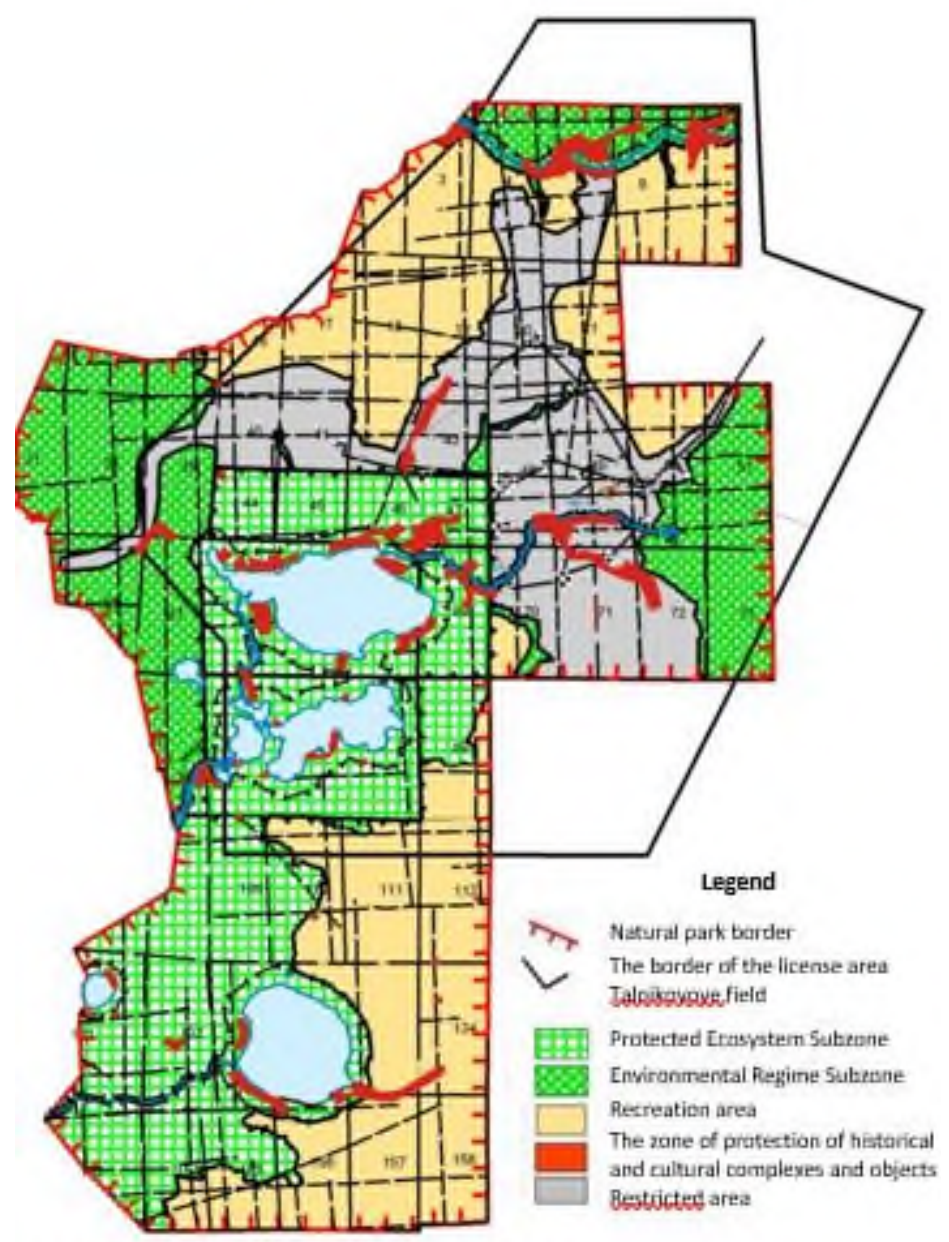

Fig. 2. Functional zoning of the territory of the natural park "Kondinsky Lakes".

Implementation of monitoring studies allows you to respond in a timely manner to changes in the main indicators characterizing the monitoring object. However, as noted above, at the level of the Khanty-Mansi Autonomous Okrug-Ugra there is no single monitoring technique for protected areas, which leads to the degradation of such natural complexes.

Currently, it is necessary to develop a methodological approach to assessing the state of protected areas objects according to uniform criteria at the regional level.

As part of the selection of the main indicators for assessing the state of the natural park "Kondinsky Lakes" of the Khanty-Mansiysk Autonomous Okrug - Ugra, it is considered possible to distribute them into three main groups: quantitative, qualitative indicators, as well as indicators of the favorableness of the components of protected areas for the development of tourist and recreational activities (Buzmakov, S. A., 2011; Bogdanova, O.V., 2018; Budarova, V.A., 2018). (table 3.) 
Table 6. Estimated indicators for assessing the status of protected areas in the Khanty-Mansiysk Autonomous Okrug - Ugra.

\begin{tabular}{|c|c|c|c|}
\hline $\begin{array}{l}\text { Monitoring } \\
\text { object }\end{array}$ & Quantitative indicators & $\begin{array}{l}\text { Qualitative } \\
\text { indicators }\end{array}$ & $\begin{array}{c}\text { Favorable indicators of } \\
\text { protected areas } \\
\text { components for the } \\
\text { development of tourist } \\
\text { and recreational } \\
\text { activities }\end{array}$ \\
\hline $\begin{array}{l}\text { Fauna and } \\
\text { flora } \\
\text { (including } \\
\text { forest } \\
\text { vegetation) }\end{array}$ & $\begin{array}{c}\text { - data on the number of rare } \\
\text { and endangered species within } \\
\text { the boundaries of protected } \\
\text { areas } \\
\text { - the dynamics of the number } \\
\text { of rare and endangered species } \\
\text { of fauna and flora } \\
\text { - the ratio of species of } \\
\text { different categories of rarity; } \\
\text { - quantitative indicator of } \\
\text { species listed in the Red Books }\end{array}$ & $\begin{array}{l}\text {-degree of disturbance } \\
\text { of vegetation } \\
\text { - disturbance and } \\
\text { damage to the stand } \\
\text { - the sanitary } \\
\text { condition of the forest } \\
\text { stand } \\
\text { - habitat quality }\end{array}$ & $\begin{array}{l}\text { - wealth of species } \\
\text { composition } \\
\text { - the presence of rare } \\
\text { species of flora and fauna } \\
\text { - landscape diversity }\end{array}$ \\
\hline $\begin{array}{l}\text { Land } \\
\text { resources }\end{array}$ & $\begin{array}{l}\text { - total land area within the } \\
\text { boundaries of protected areas } \\
\text { - the area of land within the } \\
\text { boundaries of protected areas } \\
\text { occupied by utilities, road- } \\
\text { path network, development, } \\
\text { etc. } \\
\text { - total area of sanitary and } \\
\text { protective zones of objects } \\
\text { - the area of the main } \\
\text { functional zones within the } \\
\text { boundaries of protected areas }\end{array}$ & $\begin{array}{l}\text { - the level of soil } \\
\text { pollution with oil } \\
\text { and oil products, } \\
\text { heavy metals, etc. } \\
\text { - the degree of } \\
\text { development of } \\
\text { negative natural } \\
\text { processes on lands } \\
\text { within the } \\
\text { boundaries of } \\
\text { protected areas }\end{array}$ & $\begin{array}{l}\text { - transport accessibility } \\
\text { - the possibility of } \\
\text { construction (from the } \\
\text { point of view of urban } \\
\text { planning, land, } \\
\text { environmental } \\
\text { legislation) of tourism } \\
\text { infrastructure }\end{array}$ \\
\hline Water objects & $\begin{array}{l}\text { - area of water within the } \\
\text { boundaries of protected areas }\end{array}$ & $\begin{array}{c}\text { - quality condition of } \\
\text { the water system } \\
\text { - chemical } \\
\text { composition of } \\
\text { water }\end{array}$ & $\begin{array}{c}\text { - convenience of coasts } \\
\text { for recreational } \\
\text { development } \\
\text { - availability of open } \\
\text { approaches to water } \\
\text { - sanitary and hygienic } \\
\text { conditions of water } \\
\text { bodies } \\
\text { - the ability to arrange } \\
\text { beaches and their } \\
\text { quality }\end{array}$ \\
\hline $\begin{array}{c}\text { Objects of } \\
\text { historical and } \\
\text { cultural } \\
\text { heritage }\end{array}$ & $\begin{array}{c}\text { - the number of objects of } \\
\text { historical and cultural } \\
\text { heritage }\end{array}$ & $\begin{array}{c}\text { - physical condition } \\
\text { of objects of } \\
\text { historical and } \\
\text { cultural heritage } \\
\text { - historical value }\end{array}$ & $\begin{array}{c}\text { - the status of objects of } \\
\text { historical and cultural } \\
\text { heritage } \\
\text { - the value of the object } \\
\text { (memorial, } \\
\text { architectural, urban } \\
\text { planning, artistic and } \\
\text { aesthetic) } \\
\text { - the authenticity of the } \\
\text { object }\end{array}$ \\
\hline
\end{tabular}




\begin{tabular}{|c|c|c|c|}
\hline Subsoil* & $\begin{array}{c}\text { - hydrocarbon reserves } \\
\text { - the number of valuable } \\
\text { geological objects }\end{array}$ & $\begin{array}{c}\text { - assessment of } \\
\text { hydrogeological, } \\
\text { engineering and } \\
\text { geological conditions } \\
\text { - groundwater } \\
\text { condition } \\
\text { - activity of } \\
\text { geological processes }\end{array}$ & $\begin{array}{c}\text { - the presence in the } \\
\text { territory of unique places } \\
\text { of geological nature with } \\
\text { the possibility of visiting } \\
\text { tourists }\end{array}$ \\
\hline
\end{tabular}

* if subsoil use is carried out within the boundaries of protected areas

The presented indicators can be used by state authorities of the Khanty-Mansiysk Autonomous Okrug - Ugra, local governments, organizations engaged in economic activities within the boundaries of protected areas, organizations engaged in monitoring the environment and its individual components in order to assess the state of the natural complex.

As a result of the study, it becomes possible to formulate the following conclusions:

1. Monitoring of environmental components at the level of the Khanty-Mansiysk Autonomous Okrug-Ugra is carried out by authorized state authorities at the subject level, while several state institutions may be responsible for conducting monitoring studies, which often leads to inaccuracy and incomparability of information, as well as to questions which authority is responsible.

2. The organization of integrated monitoring and inventory of protected areas was entrusted to the Department of Subsoil Use and Natural Resources of the Khanty-Mansiysk Autonomous Okrug - Ugra. However, it is worth noting that the conservation functions of unique natural complexes, landscapes and objects are carried out by budgetary institutions subordinate to the Department, which do not always have sufficient resources (technical, material, labor) for conducting quality monitoring studies.Also a significant problem is the lack of an approved methodology developed taking into account the regional characteristics of the district, including taking into account significant anthropogenic impact and severe disturbance of the territory of the subject, which impedes the fulfillment of the assigned function of conservation of protected areas.

3. Environmental monitoring includes work on the observation, assessment, prediction of the state of various components of the natural environment. However, in our opinion, depending on the level of protected areas, its goals, significance in the system of protected areas of the subject, location, natural features, absence or, conversely, the development of economic activity within the boundaries of the natural complex and other characteristics, it is necessary to determine the significance of this or that component natural environment, as well as its degree of influence on the state of protected areas.

\section{References}

1. A.A. Tranin, Territories of traditional environmental management of indigenous peoples of the Russian north (problems and prospects) 7 (2010)

2. I.N. Kustysheva, Development of methods of land protection under the objects oil and gas complex with regional peculiarities Far north 3 (2016)

3. Federal Law of 28.12.2013 № 406, http://www.consultant.ru/cons/cgi/online.cgi?req=doc\&base=LAW\&n=168138\&fld=1 $34 \& d s t=100141,0 \&$ rnd $=0.7609202955810568 \# 07747734947818912$

4. Federal law of 23.11.1995 № 174 “On ecological expertise”, http://www.consultant.ru/document/cons_doc_LAW_8515/ 
5. Federal law of 07.05.2001 49, http://www.consultant.ru/cons/cgi/online.cgi?req=doc\&base=LAW\&n=173601\&fld=1 $34 \& \mathrm{dst}=100056,0 \& \mathrm{rnd}=0.4560734709224388 \# 05813471873548395$

6. Land code of the Russian Federation of 25.10.2001 No. 136, http://www.consultant.ru/document/cons_doc_LAW_33773/

7. Law of 29.03.2018 No. 34-oz, http://docs.cntd.ru/document/543549604

8. Cadastral report on specially protected natural area natural Park regional significance "Numto», http://oopt.aari.ru/

9. G. Kozlov, M. Pushkarev, V. Mokhna E3S Web of Conferences 135, 01052 (2019) doi:10.1051/e3sconf/201913501052 